\title{
Correction to: Cost-Effectiveness Analysis of Single-Use EEG Cup Electrodes Compared with Reusable EEG Cup Electrodes
}

\author{
Anne Sohrt ${ }^{1} \cdot$ Anders Mærkedahl $^{1}$ (D) $\cdot$ William V. Padula ${ }^{2}$
}

Published online: 19 September 2018

(C) The Author(s) 2018. This article is an open access publication

\section{Correction to: PharmacoEconomics Open https://doi.org/10.1007/s41669-018-0090-3}

In the Results section of the abstract, the second sentence which previously read:

"The acquisition and reprocessing costs of single-use EEGCE were \$US5.57 and \$US3.25, respectively".

should have read:

"The acquisition and reprocessing costs of reusable EEG-CE were \$US3.25 and \$US5.57, respectively".

The article has now been corrected.

Open Access This article is distributed under the terms of the Creative Commons Attribution-NonCommercial 4.0 International License (http://creativecommons.org/licenses/by-nc/4.0/), which permits any noncommercial use, distribution, and reproduction in any medium, provided you give appropriate credit to the original author(s) and the source, provide a link to the Creative Commons license, and indicate if changes were made.

The original article can be found online at https://doi.org/10.1007/ s41669-018-0090-3.

Anders Mærkedahl

andm@ambu.com

1 Ambu A/S, Baltorpbakken 13, 2750 Ballerup, Denmark

2 Department of Health Policy and Management, Johns

Hopkins Bloomberg School of Public Health, 624 N

Broadway Ave \#456, Baltimore, MD 21205, USA 